\title{
ON THE COMPOSITION OF ANCIENT CEMENTS AND ROSENDALE CEMENTS.*
}

By A rtaur Beckwith, C. E.

The cements commonly used in New York and elsewhere for ordnary constructions, as well as for large engineering works, have frequently elicited the interest of inquirers into their nature and pro perties.

Among the best descriptions of the qualities of these cements we may cite General Gillmore's work on the subject, in which we find a list of valuable experiments which set forth the properties of various: cements, and also a table showing the chemical composition of a number of cement-stones from which our cements are made.

These experiments and tables do not, however, contain the chemical analysis of the cements themselves, upon which so much depends.

The chemical analysis of several of the Rosendale cements has lately engaged my attention, but before setting forth the results obtained I will recall briefly the history of our modern knowledge of cement.

The monuments of Egypt present one of the oldest examples of the use of lime for constructions. The mortar which joins the stone of the Pyramid of Cheops is precisely similar to modern mortars made of sand and lime. In limiting the use of mortar to filling narrow joints which separate immense blocks, and thereby reducing almast to insignificance the part which it had to play, the Egyptians seemed to forestall the influence of a dry and burning climate. Time has justified their prudence in this respect, for the works erected on the banks of the Nile by the Romans, made of small materials and presenting many joints, have left but faint traces, whilst some Egyptian temples still present themselves intact to our admiration.

Unqualified praise has often been given to the excellence of Roman mortar, and the belief is sometimes expressed that all we can hope to do is to regain the secret of making mortar once possessed by theRomans. It is a common remark that "Roman mortar has lasted for eighteen centuries, whilst a number of modern buildings are in a deplorable state of preservation."

To make a fair comparison, we should, however, only cite similar constructions, and then we are comforted by these words of Pliny: "The cause which makes so many houses fall in Rome, resides in the: bad quality of the cement."

* From the Proceedings of the A merican Society of Civil Engineera. 
Whe knowledge of the properties of lime descended from Egypt to Greece, where the exigencies of the climate and the ingenuity of the people brought forth many of its uses, unknown to Egypt.

Subsequently Greek colonies imported and popularized their processes in Italy; and Roman architects, like Vitruvius, cite the names of Greek authors on the art of construction. Their names alone have come down to us, but Vitruvius had full access to them, and in our inquiry after the knowledge of mortar possessed by the Romans, it is to him that we must refer for information. Indeed, he has left us a detailed table of precepts used by the builders of Greece and Rome, which do not justify our unreserved admiration; everything relating to lime, sand and pozzolana is clearly treated therein.

We may safely affirm, with Vitruvius, that the Romans made use of the lime, sand and materials of the countries where they built; that they considered the best lime to be produced from hard and pure marble, i. e., the fattest lime known; that in Italy they mixed it with pozzolana when used for hydraulic purposes, and that out of Italy they replaced the pozzolana from Vesuvius, by powdered brick or tile.

Roman mortars, when examined to-day, are found to bear a distinct resemblance to each other; they may be recognized by the presence of coarse sand mixed with gravel; lumps of lime are so often to be met with, that incomplete slaking will alone account for them. Mortars laid in damp spots for cisterns and pavements were composed of bricks in small fragments mixed with fat lime; this concrete required to be compacted by pounding and left to dry-the surfice was then scraped, polished and painted-evidently to prevent the dissolution of lime by water.

It will be seen by this that what we term hydraulic lime, and also the modern product of cement, were unknown to the Romans.

It is important to refute the belief that methods may have been known to them of which we have lost the secret. When the decay of arts followed upon the downfall of the Roman Empire, houses nevertheless continued to be built, and the familiar processes under the eye of the workman must have been transmitted from father to son. So true is this, that to-day Italian masons, who certainly have not read Vitruvius, make coatings for cistorns and concrete floors in the very same manner as may still be scen in the ancient ruins of Rome.

Neither is it true that Roman mortar is uniformly good. Its strength of cohesion varies in different examples from $\$ 5$ and 85 lbs. per square inch to 100 and $160 \mathrm{lbs}$, or as much as 500 per cent. 
In the middle ages a voleanic conglomerate from the banks of the Rhine, named traass, was substituted for the pozzolana of Italy, and mortar was made of fat lime, mixed with traass, to render it hydraulic

Many castles erected during that period stand well to-day; the well-known castle of the Bastile, erected in 1369-83, which after with standing a siege required the use of powder for its destruction in 1789, was found to be extremely solid even in the interior walls.

It would seem, then, that the seeret of the Romans was knowr also in those times, and could have been lost only at the Renaissance. when least of all such a supposition is probable.

At what period were first used certain limestones, having the pros. perty of producing a lime which will harden under water, is not precisely known; the first use of cement stone is cipually obscure.

In 1796 Messrs. Parker and Wyatts began to manufacture from egg-shaped limestones found near London, a product known later as. Roman Cement, aud which was soon rcceived with great favor through.. out Europe; but neither the producers nor the consumers offered an explanation of its nerits.

Not until $181 x$ and the following years was the true explanation given of the hydraulic properties of liates and cements, when Vicas published his discoveries.

Before that, in 1750, when Smeaton was preparing the arduow and bold construction of the Eddystone Lighthouse, this celebrated engineer examined with scrupulous attention the natural hydrauliolime of Aberthaw. Treated by acids it left a resilue "which appearen" to be a bluish clay, weighing about one-eighth of the total weight of the stone."

In 1786, Saussure attributed the hydraulic properties of some limes of Savoy to the combined influence of manganese, quartz, and even clay; but he left his opinions in the mere state of conjectures.

Finally, Descostils, in 1813, having discovered a considerable proportion of finely divided silica in the lime of Senonches, attributed the well-known hydraulicity of that lime to the silica it contained.

But the conjectures of Smeaton, of Saussure and of Descostic. were vague: they rested upou no proofs, and found no applications in practice.

The discoveries of Vicat attained their immediate object, for in short time artificial hydraulic lime of excellent quality was manufartured on a large scale under his direction, and a few years later he indicated as many as 100 quarries in France where hydraulic lime. stones were to be found. 
Moreover, the mortar made from his hydraulic lime equalled in hardness at the end of eighteen months the hardest ancient Romaxs mortars.

It is unnecessary to recall the evidence by which Vicat demonstrater -by analysis and by synthesis-his great discoveries. No one questions to-day the fundamental truth, that the properties of hydraulie limes depend upon the proportion of clay disseminated throughout its tissue, and that clay by being calcined acquires the property, like pozzolana or traass, of rendering fat limes hydraulic, when thoroughly diffused throughout their mass.

The labors of Vicat and Berthier have led to the following elassification of limes and cements, and consequently of limestones and cement-stones :

Table of Classification of Limes and Cements.

\begin{tabular}{|c|c|c|c|}
\hline $\begin{array}{l}\text { Proportion of elay } \\
\text { in the limestone. }\end{array}$ & & $\begin{array}{l}\text { roportion of clay } \\
\text { in the product. }\end{array}$ & (lass of lime or cement. \\
\hline Less than 10 per cent. & Or les & ss than 17 per cent. & Fat and non-bydraulic lines. \\
\hline From 10 to 15 & From & 17 to 24 & Slightly bydraulic limes. \\
\hline .15 to 17 & $"$ & 24 to 27 & Hydraulic limes. \\
\hline " 17 to 20 " & “" & 27 to 30 & Fiminently hydraulic limes. \\
\hline " 20 to $23 \quad \therefore$ & " & 30 to 34 & Limit of hydraulic limes. \\
\hline a 23 to 30 :" & $"$ & 34 to 43 & Beginning of cements. \\
\hline " 36 per cent. & " & 50 per cent. & Good hydaulic cements. \\
\hline 4) per cent. & 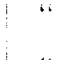 & 54 per cent. & $\begin{array}{l}\text { Hydraulic cements of diminishing } \\
\text { value. }\end{array}$ \\
\hline " 60 to 90 per ct. & “ & 73 to 94 per cent. & Tozzolan:s. \\
\hline
\end{tabular}

A point which bears directly upon our subject is the fact of the existence of a limit for the proportion of clay, at either end of the scale of cements. The transition from the properties of hydraulic lime to those of cement is not gradual, but sudden. Thus a limestone containing 20 per cent. of clay will produce an eminently hydraulic lime, but if we increase this proportion to $2: 3$ per cent., it is neither a hydraulic lime nor a tolerable cement that we have, but a worthless product, which if submerged will remain for days and ever. weeks without giving any sign of slaking, and then crumble away insensibly without effervescence; or if pulverized and tempered likt plaster, will give an appearance of setting, but crack and turn into mud when submerged.

These products, which may be called the intermediate limes, are found on an average between 20 and 23 of clay for 100 of limestone: 
but these numbers are not absolute, for some limestones containing 21 and 23 per cent. of clay make both good hydraulic lime and cement, and also the former when underburnt give very irregular results, forming sometimes a cement and at others a worthless compound.

In the same way there is a superior limit to the proportion of clay in cement, which when surpassed gives a poor cement. The exact position of this superior limit is not entirely agreed upon. It is placed at 36 per cent. and sometimes 40 per cent. by Vicat, and at 40 or 46 per cent. by Berthier.

The composition of the layers forming the quarries from which the Rosendale cements are taken is extremely variable, the proportion of elay ranging from 15 per cent. to 47 per cent. Some of these layers contain the right proportion of clay for good hydraulic limes, and for cements, while others contain the proportions which correspond to the intermediate limes and the superior limit of cements. The separate layers are not entirely uniform in their composition, and, like all beds of limestone, those situated near the surface lose a portion of their carbonic acid by the alternate action of heat and moisture.

Therefore, if the stones obtained from the different layers be mixed according to color and physical appearance, as is sometimes practised, and without a due regard to the exact chemical composition of each, it is obvious that uniform and good results are not likely to be obtained.

I am unable to give at present the result of the analysis of more than four of the different brands of Rosendale cement which $I$ have examined, and, the labor being incomplete, I refrain for the present from naming the brands which have been analyzed.

The following are the results:

Analysis of Cement No. 1.

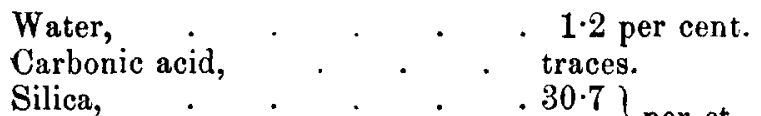

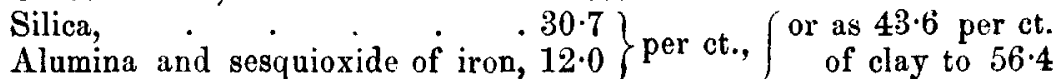
Lime, .

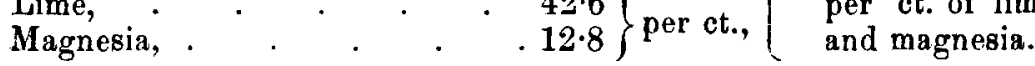

Total, . . . . $\overline{99 \cdot 3}$

Analysis of Cement No. 2.

Water, : . . . 0.2 per cent.

Carbonic acid. . . . . traces. 
Silica, . . . . . 33. ) per et., (or as 46 per cent. Alumina and sesquioxide of iron, 13. jer et., $\int$ of clay to 54 Lime, . . . . 33. per ct., $\{$ per ct. of lime Magnesia, . . . . . $20^{\circ}$ per ct., $($ and magnesia.

Total, . . . $99 \cdot 2$

Analysis of Cement No. 3.

Water, . . . . . 0.5 per cent.

Carbonic acid, . . . traces.

Silica, . . . . . 27. per ct. (or as 37 per cent.

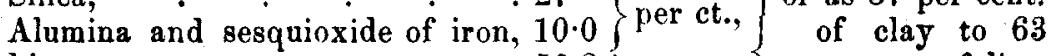
lime, . . . . . 50.3$\}$ per ct., $\{$ per ct. of lime Magnesia, . . . . . . 12. $\}$ per ct., ( and magnesia

Total, . . . . $99 \cdot 8$

Analysis of Cement No. 4.

Water, : . . . . 0.2 per cent.

Carbonic acid, . . . traces.

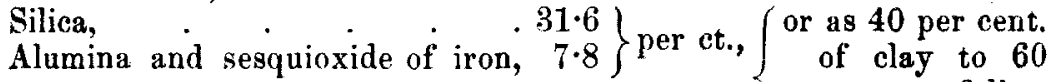

Lime and magnesia, _. bo. per ct., $\begin{aligned} & \text { per ct. of lim } \\ & \text { and magnesia. }\end{aligned}$

'Total, . . . $\overline{99 \cdot 6}$

These results show that the Rosendale cements above examined contain a proportion of clay which approaches, in some cases, to the proportion indicated by Vicat as forming the best cement, and in oth. ers to a proportion nearer the beginning of the scale of cements.

A point worthy of notice is, that if we compare these cements to the English and French cements, the one marked No. \& contains nearly the same proportion of clay as the French Portland; No. 4 contains the same as the cement of Vassy; Nos. 1 and 2 contain more clay, although nearer the proportions named by Vicat for the best cements, and all contain more magnesia than is common to European cements.

The cements examined also contain traces of alkalies and chlorides. One contained $\frac{7}{i 0 \pi}$ of sulphate of lime, which is not to be considered injurious, as it does not exceed three per eent.

The large proportion of magnesia in these cements is remarkable. 
Chemists are not wholly agreed upon the effects of magnesia in the presence of lime.

Magnesia in the presence of silica and alurnina is known to form crystallizations which resist the action of sea water better than lime -and Vicat remarks that the presence of magnesia exalts the quality of cement for marine uses.

On the other hand, it is equally certain that the silicate of magne. sia crystallizes slower than the silicate of lime, and Rigot asserts that the consequence of the presence of magnesia is disaggregation, or at least inferior hardness.

In the presence of these conflicting opinions, the true influence of magnesia remains a subject for investigation.

Having but recently analyzed various American limes and cements, I am not able to present comprehensive or complete results, and my object in introducing the subject at this stage is to call the attention and invite the labors of others, in completing the studies required for the uniform production of the best quality of hydraulic limes and cements. But my inquiries have gone far enough to convince me that standard cements will not result from experimental mixtures, not guided by selections based upon accurate analysis.

I conclude with the following analysis of Rockland lump lime:

Water and carbonic acid, . . traces.

Silica, . . . . 56$\}$ per cent., or $7 \cdot 8$ per cent. Alumina and sesquioxide of iron, $2 \cdot 2\}$ clay.

Lime, . . . . . $\quad .87 .6$ per cent., or 91.9 per cent. Magnesia, . . . $\quad 4.3\}$ lime and magnesia.

Total, . . . $\overline{.99 \cdot 7}$

Gilding Iron.-The employment of sodium amalgam is recommended by Kirchmann as a simple and effective means of covering iron with a gilded surface. The process, in brief, consists in first spreading the amalgam upon the surface of the metal, which at once coats itself with a layer of quicksilver, even though it may be somewhat rusted. Upon the surface thus prepared a concentrated solution of chloride of gold is poured and the mercury volatilized by heating before the lamp or in a furnace. The result is that a gold surface remains behind which is susceptible of a bright polish. With silver snd platinum, it is said, similar results may be obtained. 